\title{
Incorporação de óleo de laranja em hidrogel de alginato e gelatina para bioimpressão
}

\author{
João Pedro C. Caldi, Érika M. Takase, Harrson S. Santana, Mariana G.M. Lopes, Elias Tambourgi e Osvaldir P. \\ Taranto
}

\section{Resumo}

O objetivo do presente trabalho foi a incorporação do óleo essencial de laranja em hidrogéis de alginato e gelatina. Esse óleo foi incorporado a uma solução de hidrogel de alginato $(2 \% \mathrm{~m} / \mathrm{v})$ e gelatina $(10 \% \mathrm{~m} / \mathrm{v})$, sendo testado para três diferentes concentrações de óleo: 2,5 e $10 \% \mathrm{~m} / \mathrm{v}$. Dentre cada um dos três casos, aquele cujo óleo essencial se encontrava na concentração de $5 \%$ se mostrou o melhor, apresentando uma incorporação mais uniforme, além de menor formação de emulsão tanto na preparação da solução quanto após o processo de preparação.

Palavras-chave:

Hidrogéis, Óleo Essencial de Laranja, Microfluídica.

\section{Introdução}

A bioimpressão 3D é a extrusão de forma contínua de biotinta (i.e., hidrogel composto por células), em um recipiente por um extrusor móvel que formam padrões, pré-definidos por ferramentas de desenho 3D, com o objetivo de obter tecidos e órgãos ${ }^{1}$ a partir de biotintas compostas de células vivas. Para avançar nesse campo, - estudo de compostos orgânicos incorporados nas biotintas são de grande interesse, pois permite a análise de como se dará a interação destes com o hidrogel, e a comparação entre as propriedades dos compostos antes e após a incorporação, para inicial entendimento do comportamento da biotinta.

Em virtude disso, o objetivo desse trabalho foi a incorporação do óleo essencial de laranja em hidrogéis de alginato e gelatina.

\section{Resultados e Discussão}

O estudo começou a partir da preparação dos hidrogéis: em $10 \mathrm{~mL}$ de água destilada, dissolvia-se, sob constante agitação durante $12 \mathrm{~h}$ e temperatura ambiente, o alginato de sódio (cujas concentrações variavam entre 2 e 10\% $\mathrm{m} / \mathrm{v}$, dependendo da amostra), e, após homogeneização, a gelatina comercial (cujas concentrações variavam entre 2 e $10 \% \mathrm{~m} / \mathrm{v}$, depedendo da amostra) e PEG (Polietilenoglicol) 1500 (cujas concentrações variavam entre 0,5 e $1,5 \% \mathrm{~m} / \mathrm{v}$ ). Para analisar a precisão de impressão de cada amostra, foi utilizado um Delineamento Composto Central Rotacional (DCCR) com 17 ensaios em diferentes condições, sendo que para cada uma destas, foram realizados testes de impressão (Figura 1a), a partir de um modelo digital (Figura 1b) feito com o programa Autodesk Inventor, a fim de analisar qual composição da solução (i.e., concentração de alginato, gelatina e PEG) apresentava melhor precisão de impressão ${ }^{2}$, que relaciona a área impressa da solução - obtida pelo tratamento da imagem com a ajuda do programa ImageJ - e área do modelo digital calculada pelo Autodesk Inventor.

Todos esses resultados obtidos pelos testes de impressão foram analisados com o software Statistica, que tratou os resultados, correlacionando-os a cada uma das variáveis, indicando quais entre elas apresentavam maior influência no resultado final e qual a melhor composição para obter a melhor precisão de impressão.

Ao final da análise, observou-se que a gelatina e o alginato de sódio eram as variáveis de maior influência, porém, não apresentavam bons resultados quando em proporções semelhantes, o que corroborou com o resultado de que a melhor composição para se trabalhar era de $2 \% \mathrm{~m} / \mathrm{v}$ de alginato e $10 \% \mathrm{~m} / \mathrm{v}$ de gelatina, os extremos do intervalo de concentrações testadas para cada uma, sendo que o PEG apresentou influência quase nula na precisão de impressão, e sua melhor concentração sendo de $1 \% \mathrm{~m} / \mathrm{v}$.

Figura 1: Padrão impresso em 3D (a) e Modelo digital (b)
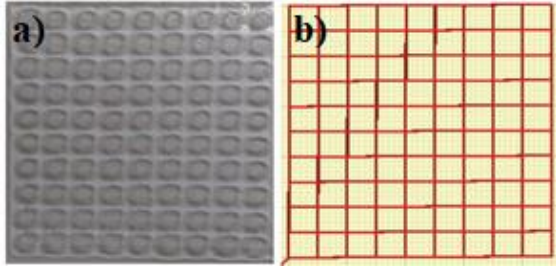

Tendo a composição do hidrogel definida, o óleo essencial da casca da laranja (extraído por prensagem da casca da fruta, composição 96\% Limoneno, empresa Phytoterápica), foi incorporado a solução de hidrogel, sendo esse processo repetido para três diferentes concentrações de óleo (2, 5 e 10\%) para analisar a precisão de impressão (Tabela 1), cujos resultados indicam que a amostra de $5 \%$ é a melhor.

Estas três amostras também foram analisadas quanto a sua incorporação por análises de MEV, IV e TGA, que revelaram que a amostra de $5 \% \mathrm{~m} / \mathrm{v}$ de óleo essencial apresentou uma melhor incorporação, mais uniforme, uma vez que apresenta menor quantidade de bolhas de emulsão, que indicam a não incorporação do óleo.

Tabela 1: Precisão de impressão (\%) após incorporação

\begin{tabular}{ccc}
\hline Óleo $2 \% \mathrm{~m} / \mathbf{v}$ & Óleo $5 \% \mathrm{~m} / \mathbf{v}$ & Óleo $\mathbf{1 0} \% \mathbf{~ m} / \mathbf{v}$ \\
\hline $57 \pm 8$ & $69 \pm 4$ & $68 \pm 7$ \\
\hline
\end{tabular}

\section{Conclusões}

Como visto pelos resultados acima, a composição de $5 \%$ $\mathrm{m} / \mathrm{v}$ óleo essencial foi a que mostrou melhores resultados de precisão de impressão $(69 \pm 4 \%)$, sendo também a composição de melhores resultados no estudo da incorporação do óleo essencial.

\section{Agradecimentos}

Este projeto foi apoiado pela CNPq

${ }^{1}$ Skardal, A. Multi-tissue interactions in a integrated three-tissue organ-on-achip platform, Nature, 2017.

2 Giuseppe, M. D. Mechanical behavior of alginate-gelatin hydrogels for 3D bioprinting. Elsevier, 2018. 